\title{
Globalization and the Demise of Policy Sovereignty: A Perspective of the Developing Countries
}

\author{
Dereje Terefe $(\mathrm{PhD})$ \\ Associate Professor, Social \& Public Policy, School of Policy Studies, ECSU, Addis Ababa, Ethiopia
}

\begin{abstract}
Unaware of what globalization is destined to, in the past three to four decades, naivety is abounding as if we had and still continue to have exclusive policy sovereignty of our own domestic policies. Today, the idea of domestic or sovereignty over one's own policy seems simply a memory of past narrative that may not match with the tenets and real practices of the unprecedentedly globalizing world. Consequently, the concepts 'globalization' and domestic or 'sovereign' public policies are becoming asymmetrical, lacking in common meeting grounds. The objective of this article is to draw the attention of a range of policy actors to become aware of the incongruity between globalization and policy sovereignty on one hand, and the inevitability of the advance of globalization and the need to rise up as strong competitor to survive and face head-on the likely predicaments that may result in, on the other.
\end{abstract}

Keywords: Globalization, Public policy, Domestic policy, Policy sovereignty, Competition, and Knowledge economy

DOI: $10.7176 / \mathrm{PPAR} / 9-9-03$

Publication date:September $30^{\text {th }} 2019$

\section{Introduction}

It has been since awhile that globalization has become a catch phrase for almost all walks of life. In view of Radice Hugo, "globalization has become a major discourse topic among geographers, sociologists as well as economists and political scientists, and is studied within every paradigm, from neoclassical economics to postmodern social theory to realist international relations theory to Marxism" ${ }^{\text {. }}$. While some question the clarity, scope, and prevalence of globalization, others argue that it has been part of human history, movement history as a result of which there has now come old distinction between international and domestic policies, where the notion of the former tends to become increasingly irrelevant. ${ }^{2}$ The issue now is what really is globalization? Definitions for the subject are not only numerous, but understanding of its notions also dramatically vary from persons to persons, scholars to scholars.

Some further argue that the notion of globalization is geographic determinant; it is what we feel where we are and how to deal with our life style taking into consideration of others. For example, Jan A. Scholte (2000) argues that "globalization refers to processes whereby many social relations become relatively delinked from territorial geography, so that human lives are increasingly being played out in the world as a single place" (p.6). Others characterize globalization as "the process of increasing inter-connectedness between societies such that events in one part of the world more and more have effects on peoples and societies faraway"3. To the view of Anthony Giddens, globalization is a phenomenon of "the intensification of worldwide social relations which link distant localities in such a way that local happenings are shaped by events occurring many miles away and vice versa"4.

The International labor organization (ILO) defines globalization as a process of growing interdependence between all people of the planet. Accordingly, people are linked together economically and socially by trade, investments and governance. Such links are spurred by market liberalization and information, communication and transportation technologies. In consequence, global economy was already in existence since the $16^{\text {th }}$ century, based on the development of international trade, foreign direct investment and migration. ${ }^{5}$ In political terms, globalization is defined as the expansion and intensification of international political and economic intercourse. This results in economic and political interdependence. It also goes that the intensity, speed, and volume of global interactions show increasing interdependence, which also hints to examine international relations via global governance. ${ }^{6}$

While globalization is considered to accord benefits to everyone in generating wealth, delivering cheaper and varied products and services and encouraging democratization, there are equally skepticisms that the overwhelming majority of foreign investments largely occur between the world's richest nations. As a result,

\footnotetext{
${ }^{1}$ Radice Hugo, "Responses to Globalization: A Critique of Progressive Nationalism..." (2000)

${ }^{2}$ Greg Nzeken, “Contemporary Experiences in Globalization”... (1999, 30)

${ }^{3}$ Steve Smith and John Baylis, cited ibid.

${ }^{4}$ A. Giddens, The consequences od Modernity. Stanford: Stanford University Press. (1990) 64

${ }^{5}$ Globalization and Workers'Rights, International Labor Office, ILO. Available at http://w.w.w.ilo.org/actray

${ }^{6}$ Michael Barnet and Raymond Duvall, "Introduction" in Global Governance, 2005
} 
most small states believe that globalization lead to the dominance of the weak by the rich and powerful states. This would take us to the ever-unending discourse with regard to sovereignty, global governance, and national or domestic public policy.

As used to be the norm, sovereignty signifies both the right to act and a power to act. Consequently, sovereignty may be defined more specifically as the right to ultimate or final decision about the terms of existence of a whole territorially-based body politic. This upholds the view that there is neither external superior nor internal rival. In other words, there is no external body that has the right to command or order a sovereign state to act in a given way with regard to issues of fundamental concern to it. ${ }^{1}$ One main aspect of sovereignty is based on recognition by other sovereigns to garner relationship with other states.

Modern notion of sovereignty is believed to have emerged from the reactions of European states to the doctrine of the Holy Roman Empire that was created in 962 A.D. The doctrine holds that the Emperor was superior to all governments, monarchies or republics of the Christian countries. The reaction was directed at the superiority of the Pop overall Christian rulers. ${ }^{2}$ In the $16^{\text {th }}$ and 17 th century of Europe, political scientists such as Niccolo Machiavelli advocated for the security of the prince and the stability of the state. On the other hand, John Locke and Jean Jacques Rousseau opposed to this view by replacing it by the people constitution the sovereign. Rousseau further argued that an individual is not be held subject to another other than the will of the community (people). ${ }^{3}$

Before winding up the issue of sovereignty, it is important to look at the classical treaty known as Westphalia and Westphalian sovereignty. Wikipedia, the free encyclopedia, calls it as 'Westphalian sovereignty', or 'state sovereignty'. It was considered the principle in international law that each nation state has exclusive sovereignty over its territory. Consequently, Westphalian sovereignty had evolved into modern international system of sovereign states to have been later enshrined in the United Nations Charter, which states: "Nothing should authorize intervention in matters essentially within the domestic jurisdiction of any state" 4 . This became the beginning of modern international system, in which external powers had to refrain from interfering in another country's domestic affairs.

On the other hand, it's important to note that Westphalian sovereignty is historically traced back in the scholarly literature to the Peace of Westphalia which took place in 1648 in Germany, Europe. The Peace is considered a watershed that ended the "Thirty Years' War" that had an enduring devastation over religion in Germany which was believed to have sacrificed $30 \%$ of its population, where neither the Catholics nor the Protestants had claimed a clear victory. The historic peace settlement established a status quo order to which states in Europe complied with no intention of interfering in each other's religious practices. ${ }^{5}$

Westphalia was further developed in the $18^{\text {th }}$ century and reached its peak in the $19^{\text {th }}$ and $20^{\text {th }}$ centuries, before it faced serious challenges and oppositions. Today, the principle of Westphalia or non-interference into the affairs of other nations is considered simply a shorthand claim for the basic legal principles underlying the modern state system. Its real application and relevance has been questioned since the mid- $20^{\text {th }}$ century from a variety of viewpoints, mainly on the advancing ideas such as internationalism and globalization, having conflictual standpoints with Westphalian sovereignty. In the subsequent paragraphs, the eminent Westphalian challenges and oppositions will be examined.

Challenges and opposition towards Westphalian order which also became the basis of the modern United Nations "non-interference" in the sovereign states began to take shape in the aftermath of the Cold War. This was precipitated by international integration and the erosion of Westphalian sovereignty. ${ }^{6}$ This began during the 1998 NATO's Symposium which emerged to question the political relevance of the treaty. The underlying triggering and plausible argument was that "humanity and democracy", which are considered to be the common principles of contemporary nation-states could not go hand-in-hand with the Westphalian sovereignty order and to prove it as irrelevant. Hence, the then NATO Secretary-General, Javier Solana, argued that the principle of Westphalian sovereignty had its limitations and resulting in exclusion rather than integrating of community of states $^{7}$. In a similar vein, former British Prime Minister, Tony Blair, in his 1999 Chicago speech sought a new post-Westphalian, known as 'doctrine of the international community' since globalization had made the former anachronistic, simply to characterize it as 'past mistake' that lost time relevance ${ }^{8}$. With this, Blair was labeled as "the man who ushered in the post-Westphalian era" (Mike 2012).

With the rise of terror attacks in the West, different institutions had to re-examine their previous treaties

\footnotetext{
${ }^{1}$ Murray Greensmith F. 2000

${ }^{2}$ B.O.Okere, "Evolution of the Concept of Sovereignty", Lecture Note. Faculty of Law, UNEC. P. 3

${ }^{3}$ Jacques Maritain, 'The Concept of Sovereignty', vol. X/iv. American Political Science Review, 1950, p. 353. Cited in B.O.Okere, Ibid., p.9

4 The Economist, 15 May 2008.

${ }^{5}$ Kissinger, Henry (2014). World Order. ISBN 978-0-698-16572-4

${ }^{6}$ Camilleri and Falk, The End of Sovereignty? 1992

${ }^{7}$ Solana, Javier (1998), Securing Peace in Europe, North Atlantic Treaty Organization, retrieved 2008-05-21

${ }^{8}$ Harris, Mike, "Why is Tony Blair lending credibility to Kazakhstan's dictator?", The Telegraph, February 2, 2012
} 
seeking for what is known as the new international system ${ }^{l}$. Notable global institutions such as the European Union came to explain the asymmetry between shared sovereignty concept that provides for external agents to influence and interfere in the internal affairs of its member countries and the historical Westphalian sovereignty. Added to this, the rise of terrorism and the behavior of some states could not be a valid proof for the status quo principle. This all justified military interventions such as Cambodia by Vietnam, Bangladesh by India ${ }^{2}$ and subsequent interventions in the Middle East such in Afghanistan, Iraq, and now in Syria and Yemen. According to Daniel Philpott (2001), during the past decade alone, the United Nations has lent its imprimatur to intervention in war-torn, malnourished, dictatorial, and monitoring persecuting states, in Iraq, Somalia, Haiti, Rwanda, Bosnia, Liberia, and elsewhere.

Many European states have formed a European Union, creating, among other things a common currency, continuing an amalgamation of governance that began in 1950. Intervention and integration challenge the sovereign state's territorial supremacy, when seen in the light of both the Westphalian and the United Nations' non-interference corner stone as well as the basis of its founding principles, after the two historic bloody wars. On the other hand, many of the interventions made were labeled as 'humanitarian interventions', although their basis in international law is debatable. This also led to what is known as a new contingent sovereignty to emerge and assumed international legitimacy in some of the recent military interventions that resulted in the infringements of state sovereignty whose legality and motivations are unclear ${ }^{3}$.

Consequently, Daniel characterized the U-turn to the long revered sovereignty of states as sweeping "revolutions" (revolutions in sovereignty), having far-reaching impacts not only in the political spheres but also in public policy arenas.

\section{Policy sovereignty in the era of globalization}

Scholars have it that we had lived in a world of essentially unchallenged sovereignty for several generations now, and had begun to think of it as the natural state of affairs. But just as the idea of states as autonomous and independent entities is collapsing under the combined onslaught of monetary unions, global television such as $\mathrm{CNN}$, the Internet, governmental and non-governmental organizations, the issue of policy sovereignty could not stand in isolation. It can be recalled that since the passage of the Rio Summit (1992), there has grown a surge of optimism about multilateral treaties. This led to some level of 'universal' compliance and effectiveness.

In consequence, newer generation of treaties, dominated for the study of international institutions for a decade. In particular, environment issues became a laboratory of exploring questions of compliance and effectiveness in areas such as the protection of endangered species, regulation of chemicals or emissions, protection of biodiversity. All of have these influenced domestic practices, policies and policy-making processes rather than simply to constrain or modify the external behavior of states (Bernstein and Cashore 2012). In most global governance literatures, the concept 'effectiveness' became the ultimate litmus test of almost all nation states which has direct implications to domestic policies of the same (Hass 1989).

The condition under which institutions, treaties and organizations induce compliance was directed at measuring the 'collective optimum', the point at which no nation can benefit more without harming another nation (Underdal 1992). This in turn made to enhance the compliance of stated goals of the agreement under question (Mitchell 2006). In response, states no longer could have a control and full governance on their policies. For instance, climate change, forest degradation and biodiversity loss are but three prominent examples of issues governed by an array of mechanisms that include legal, non-legal, governmental and non-governmental arrangements.

One of the areas in which national (domestic) public policies are influenced or affected are by international institutions. What do international institutions do? They provide for governmental, sub governmental and transitional actors to interact and facilitate rule creation and norms of appropriate behavior. This in turn helps in coalition-building which may be important for applying authoritative rules to be complied with. To this end, international institutions, specifically, international non-governmental organizations (INGOs), can be authoritative sources of rules to which states or firms have commit (Bernstein \& Cashore 2007; Vogel 2008).

International institutions, therefore, pose greater influence through each issue-specific treaties and policy prescriptions through powerful international organizations such as the World Bank or IMF, whether perceived as resting on consent, also known as "harmonization", or coercion. The logic of this pathway is that rules are binding and create a 'pull toward compliance', because they came into being by generally accepted rules of right process, regardless of whether they are enforced (Frank 1990). In concrete terms, it's important to know what exactly international agreements and complex global governance do to domestic policies as follow:

a) They influence domestic policy to the extent that they create binding obligations on states through

\footnotetext{
1 "Center for Security Studies, ETH Zürich". Retrieved 2018-12-18.

2 Michael Akehurst, "Humanitarian Intervention", in H. Bull, ed., Intervention in World Politics, Oxford University Press, 1984

${ }^{3}$ Ibid.
} 
international law. Such binding rules carry their own logic of influence.

b) Transnational and/or domestic coalitions for change can activate rules in case of non-compliance. But the logic of rules can be a resource on which transnational and/or coalitions of domestic actors draw when governments do not comply, although the ability to mobilize may vary across domestic settings. When such mobilization is possible, groups can publicize non-compliance and put pressure on governments to launch dispute against other countries that do not fulfil their obligation (Bernstein and Cashore 2007).

c) Dependent countries on trade or foreign capital under conditions of increasing globalization fear of losing market share and investor confidence. These serve as an added incentive to comply with international rules which has greater impact on domestic policies.

d) Agreements on international rules with strong compliance mechanisms are more likely when such agreements reflect rules or processes already under way domestically owing to interaction.

From the aforementioned areas of complex influence on domestic public policy of nation-states, one can clearly understand that though international norms are not entrenched in hard law and non-binding in developing nations, it relies more heavily on logic of appropriateness, which tacitly implies compliance. It is also the case that norms agreed to at the international forums and promoted by powerful or influential organizations influence the direction of policy change when governments face external pressures to change policies. To this end, a series of strategies that transnational actors undertake tempt and sometimes coerce states to adhere to norms (Keck and Sikkink 1998).

Consequently, when domestic structures or networks try to resist such alien norms and compliance, they induce domestic actors to resort to the international level to seek allies and bring scrutiny to bear (Keck and Sikkink 1998). Furthermore, learning gained through interaction in transnational networks, explicit efforts at dialogue, and/or participation in formal and informal international gatherings or conferences and transnational networks are also unique opportunities for international actors for the dissemination of possible transformation or norms (Holzinger et al., 2004), which play significant role to influence and change national policies to unchartered course of action.

Countries that have active involvement in multinational decision-making can provide domestic policymakers with opportunities as well as constraining them. Hence, domestic policy actors can only use international opportunities to capture resources. When domestic actors can use multinational level processes to alter domestic policymaking arrangements, things can be in their favor (Lodge 200; Radaellic 2003; Janes 2010). In conclusion, globalization and cross-national pressures have not only abolished the role of the state, but they have also altered the scale at which policy is made and implemented or delivered (Jessop 2000). Changing the locus of policymaking has equally altered radically power relationships between international actors and that of the domestic, which also led to a scenario where it has become more difficult entirely to separate what can be called domestic from cross-national, even at times international policies.

As mentioned elsewhere in this article, there are varieties of influence that occur through direct funding, education, training, assistance and capacity-building, and possibly through attempts at co-governance through partnerships created between domestic and international public and private actors and authorities (Bernstein \& Cashore 2012). Similarly, non-domestic actors are made to avoid direct lobbying or other perceived challenges to state autonomy in favor of strategies that alter the balance of power among existing domestic organized interests or their participation in policy networks. In fact, one of the mechanisms transnational actors accomplish their mission is by sharing resources, ideas, knowledge and expertise with existing groups, or by facilitating the creation of new groups or coalitions. One consequence of the above national predicaments is policy transfer (voluntary or coercive). But policy transfer in either form results in what is considered as "policy autonomy anxiety' and operating in policy "straightjacket" from developed to developing countries.

There are, however, counter-arguments surfacing against the lack of policy autonomy as a result of globalization and international governing institutions. For instance, on a study conducted in Brazil and Mexico on the level of policy autonomy, Alvaro Santos (2012) has come up with a consoling finding where both countries, despite opening themselves to global market driven by the World Trade Organization (WTO) could, however, retain their policy autonomy.

\section{In lieu of Conclusion}

Globalization has surpassed what it used to seem as myth. It's a reality we live keep living every day. Its social, economic, political, cultural and technological reach is enormous. Long before it has reached to this stage, discourses were to have it as means to 'even' distribution of global wealth for global wellbeing and harmony. But as Bob Deacon (2012) observed, effective redistribution and socially responsible state of affairs is not yet forthcoming. Instead, existing global arrangements for economic and social governance prevent countries from having autonomy over their policy options that might increase equity and continued to contribute to the prevalence of inequities. On the other hand, in the face of the almost irreversible nature of ever-advancing 
globalization, countries, developing ones in particular, are left with two main options: strengthening their competitiveness and build the knowledge economy in a bid to have policy bargaining capacity and restore their policy autonomy.

\section{References}

1. Bernstein, Steven and Cashore, Benjamin 2012. Complex global governance and domestic policies: four pathways of influence

2. Castles, Francis Geoffrey. 1988. Australian public policy and economic vulnerability: A comparative and historical perspective. Sydney;Boston: Allen \& Unwin

3. --------1998. Comparative Public Policy: Patterns of Post-War Transformation. KU: Edward Elgar P.L.

4. Deacon, B. 2016. Assessing the SDGs from the stand point of global social governance. Journal of International and Comparative Social Policy, No. 32, Vol. 2.

5. Dimaggio, P. J. and Powell, W. W. 1991. "The Iron Cage Revisited: Institutional Isomorphism and Collective Rationality in Organization Fields', in W.W. Powell and P. J. Dimaggio, The New Institutionalism in Organizational Analysis. Chicago IL: University of Chicago Press, pp.63-82

6. Dolowitz, David \& Marsh, David.1996. 'Who Learns from Whom: A Review of the Policy Transfer Literature'. Political Studies, 44 (2): 343-57

7. ------------ 2000.'Learning From Abroad: The Role of Policy Transfer in Contemporary Policy making', Governance 13 (1): 5-24

8. Drezner, Daniel W. 2001. Globalization and policy convergence. USA: Blackwell Publishers

9. Engeli, Isabelle and Allison, Christine R. 2014. Comparative Policy Studies: Conceptual \& Methodological Challenges. London: Palgrave Macmillan Books

10. Evans, M. 2009a. Policy transfer in Critical perspective, Policy Studies, 30 (3), 243-268

11. ------ 2009b. New directions in the study of policy transfer. Policy Studies 12 (5), 817-840

12. Evans, Mark and Davies, Jonathon. 1999. 'Understanding Policy Transfer: A Multi-level, Multidisciplinary Perspective", Public Administration,77 (2) 361-85

13. Faur, David Levi and Gadot, Eran V. 2004 (eds.) International Public Policy and Management: Policy learning beyond regional, cultural, and political boundaries. New York: Marcel Dekker

14. Feldman, Elliot. 1978. "Comparative Public Policy: Field or Method?" Comparative Politics 10 (2): $287-$ 305

15. Friedman, Thomas. 1999. The Lexus and Oliver Tree. New York: Farrar, Straus, and Giroux, p. 86

16. Global governance and governance of the global commons in the global partnership for development beyond 2015. January 2013.

17. Gupta, Kuhika. 2012 Comparative public policy: Using the Comparative Method to advance our understanding of the policy process. Policy Studies Journal Vol. 40, No. 51

18. Hall, Peter. 1993. 'Policy Paradigms, Social Learning and the State: The Case of Economic Policy making in Britain', Comparative Politics, 25: 275-97.

19. Heclo, Hugh. 1974. Modern Social Politics in Britain and Sweden: From relief to income Maintenance. New haven: Yale University Press

20. Holzinger, K and Knill, C. 2005. "Causes and conditions of cross-national Policy convergence', Journal of European Public Policy 12 (5)

21. International Institution and the Global Governance Program World Order in the $21^{\text {st }}$ Century, 2008: A new initiative of the Council on Foreign Relations

22. Kerr, Clark. 1983. The Future of Industrial Societies: Convergence of Continuing and Diversity? Cambridge, Mass.: Harvard University Press (p. 3)

23. Knill, Christoph and Tosun, Jale. 2012. Public policy: A New Introduction. Great Britain: Palgrave Macmillan

24. Knill, Christoph.2005. Introduction: Cross-national policy convergence: Concepts,Approaches and explanatory factors: Journal of Public Policy. Vol. 12, 5 (2005)

25. Levi- Faur, D. 2005. "The global diffusion of regulatory capitalism", The Annals of the American Academy of Political and Social Science (Special Issue: The Rise of Regulatory Capitalism: The Global Diffusion of a New Order, Guest Editors: D. Levi-Faur and J. Jordana) 598: 12-32.

26. Mills, John S. 1843. Two Methods of Comparison, selection from his "A System of login, New York: Harper \& Row Publishers, 1888 PP.272, 279-283

27. Moran, Michael, Rein, Martin and Goodin, E. Robert (eds.). 2006. The Oxford Handbook of Public Policy. Oxford: Oxford University Press

28. James, Oliver \& Lodge, Martin. 2003. The Limitations of 'Policy Transfer' and 'Lesson Drawing' for Public Policy. Political Studies Review Vol.1, 179- 193, UK: Blackwell Publishing

29. Oliver, M. and Pemberton, H. 2001. "Learning and Change in Twentieth Century British Economic Policy', 
Paper presented to European Association for Evolutionary Political Economy Conference, Siena, 8-11 November 2001

30. Rogers, E. M. 1995. Diffusion of Innovation, New York: Free Press

31. ------2003. The Diffusion of Innovations. Free press, New York

32. Rose, Richard. 1991. "Comparing Forms of comparative Analysis."Political Studies 39 (3): $446-462$

33. -------1993. Lesson-Drawing in public policy. Chatham, NJ: Chatham House

34. ----------2005.Learning from Comparative Public Policy: A Practical Guide, London: Routledge

35. Santos, Alvaro. 2012 Carving Out Policy Autonomy for Developing Countries in the World Trade Organization: The Experience of Brazil and Mexico. Georgetown University Law Center, asantos@law.georgetown.edu

36. Simmons, B.A. and Elkins, Z. 2004. 'The globalization of liberalization:policy diffusion in the international political economy', American Political Science review 98: 171-89.

37. Underdal, Aril. 1992. The of regime "effectiveness", Cooperation and Conflict 27:3, 1992, pp.227-40: Peter M. Haas, Robbert O. Keohane and Marc

38. Weiss, Thomas G, Seyle, Conor D, and Coolidge, Kelsey. 2013. The Rise of Non-State Actors in Global Governance: Opportunities and Limitations: 2013 One Earth Future Foundations

39. Wiarda, Howard J. 2007. Globalization: Universal trends, regional Implications, Boston: University press of New England 